\title{
Additions to reviewing the genus Clytellus Westwood, 1853 (Coleoptera: Cerambycidae). 2
}

\section{Аополнения к обзору рода Clytellus Westwood, 1853 (Coleoptera: Cerambycidae). 2}

\author{
A.I. Miroshnikov ${ }^{1,2}$, T. Tichý' \\ А.И. Мирошников ${ }^{1,2}$, Т. Тихий ${ }^{3}$
}

\author{
${ }^{1}$ Russian Entomological Society, Krasnodar, Russia. E-mail: miroshnikov-ai@yandex.ru \\ ${ }^{2}$ Sochi National Park, Moskovskaya str., 21, Sochi, Krasnodar Region 354002 Russia \\ ${ }^{3}$ Technical University of Ostrava, Sokolska str., 33, Ostrava 70121 Czech Republic \\ ${ }^{1}$ Русское энтомологическое общество, Краснодар, Россия \\ ${ }^{2}$ Сочинский национальный парк, ум. Московская, 21, Сочи, Краснодарский край 354000 Россия \\ ${ }^{3}$ Остравский технический университет, Острава, Чешская Республика
}

Key words: Coleoptera, Cerambycidae, Clytellina, Clytellus, new species, new records, Philippines, Malaysia. Ключевые слова: Coleoptera, Cerambycidae, Clytellina, Clytellus, новый виА, новые находки, Филиппины, Малайзия.

Abstract. A new species, Clytellus philippinus Miroshnikov et Tichý, sp. n. resembling C. tatianae Miroshnikov, 2014, is described from the southern part of the Philippine Archipelago. New localities are given for C. shibatai Hayashi, 1977, C. malayanus Hayashi, 1977 and C. mononychus Holzschuh, 2003, thereby representing the southernmost record of the former species.

Резюме. Описывается новый виА Clytellus philippinus Miroshnikov et Tichý, sp. n. из южной части Фикиппинского архипелага, похожий на C. tatianae Miroshnikov, 2014. Ааются новые местонахождения C. shibatai Hayashi, 1977, C. malayanus Hayashi, 1977 и C. mononychus Holzschuh, 2003 в Западной Малайзии, причем Аля первого вида ранее не известная находка явАяется самой южной.

The present paper replenishes the composition of the genus Clytellus Westwood, 1853, through the description of a new species from the Philippines. It seems noteworthy that only 3 members of the genus have hitherto been known from that archipelago [Miroshnikov, 2014, 2015].

In addition, new data on the distribution of some species are given, the underlying specimens of which have been restudied by one of the authors ( $\mathrm{T}$. Tichý) in the collection of the National Museum of Natural History, Smithsonian Institution (Washington D.C., USA) during a visit to that museum. The other author has examined pictures of these specimens.

The material treated in this paper belongs to the following institutional and private collections:

USNM - National Museum of Natural History, Smithsonian Institution (Washington D.C., USA);

cAM - collection of Alexandr Miroshnikov (Krasnodar, Russia);

cLD - collection of Luboš Dembický (Brno, Czech Republic);

cTT - collection of Tomáš Tichý (Opava, Czech Republic).
Clytellus philippinus Miroshnikov et Tichý, sp. n. (Color plate 9: 1-4; Color plate 10: 10, 11)

Material. Holotype, ㅇ (cTT): Philippines, Negros, Central Visayas, $\sim 10^{\circ} 19^{\prime} \mathrm{N} / 123^{\circ} 52^{\prime} \mathrm{E}, 05.2013$ (native collector). Paratype: 19 (USNM), “[Philippines] Island of Basilan [ $\left.6^{\circ} 34^{\prime} \mathrm{N} / 122^{\circ} 02^{\prime} \mathrm{E}\right]$, Baker".

Comparative material. Clytellus tatianae Miroshnikov, 2014: holotype, ( (cLD), W Malaysia, Johor, $15 \mathrm{~km}$ NW Kota Tinggi, Muntahak Mt., 200 m, 7-13.03.2002 (leg. P. Čechovský); 2 (USNM), "Brunei, Waterstradt",

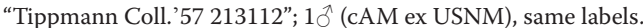

Clytellus jenisi Miroshnikov, 2015: holotype, ㅇ (cLD), E Malaysia, Sabah, Bajnaran Maitland, Sapulut, 4'42'N / 116 29 'E, 22-24.05.1995 (leg. Ivo Jenis).

Diagnosis. The new species is very similar to C. tatianae Miroshnikov, 2014 (Color plate 9: 5-9; Color plate 10: 12-14), but differs by the somewhat special structure of the elytra, in particular, the clearly more abundant erect, coarse, light setae at their apex (this is especially noticeable in the holotype with such setae being entirely preserved), the longitudinal row of coarse or rough, oblong-oval, coalescing or connivent punctures in the form of a groove on the sides being less strongly developed and less proximate to the base of the elytra, as well as by the special structure of the pronotum, in particular, the less strongly developed fascia of dense, recumbent, light setae at its base, the relatively uniform sculpture on the disk (without clear, longitudinal, oval, dull spot of microsculpture), its less strongly convex shape, the shorter and, partly, less coarse longitudinal grooves in the area of constriction in front of the base, the generally darker antennae and legs, obviously on the average a larger body. Clytellus philippinus sp. n. can also be compared to C. jenisi Miroshnikov, 2015, but differs clearly at least in the structure of the elytra, including the less coarse puncturation in their basal half, the apical one-third being less strongly narrowed towards apex, the particularity of the distribution of erect, coarse setae in the apical part, as well as by the structure of the pronotum, in particular, the less strongly developed fascia of dense, recumbent, white setae at its base, the shorter and, partly, less coarse, 


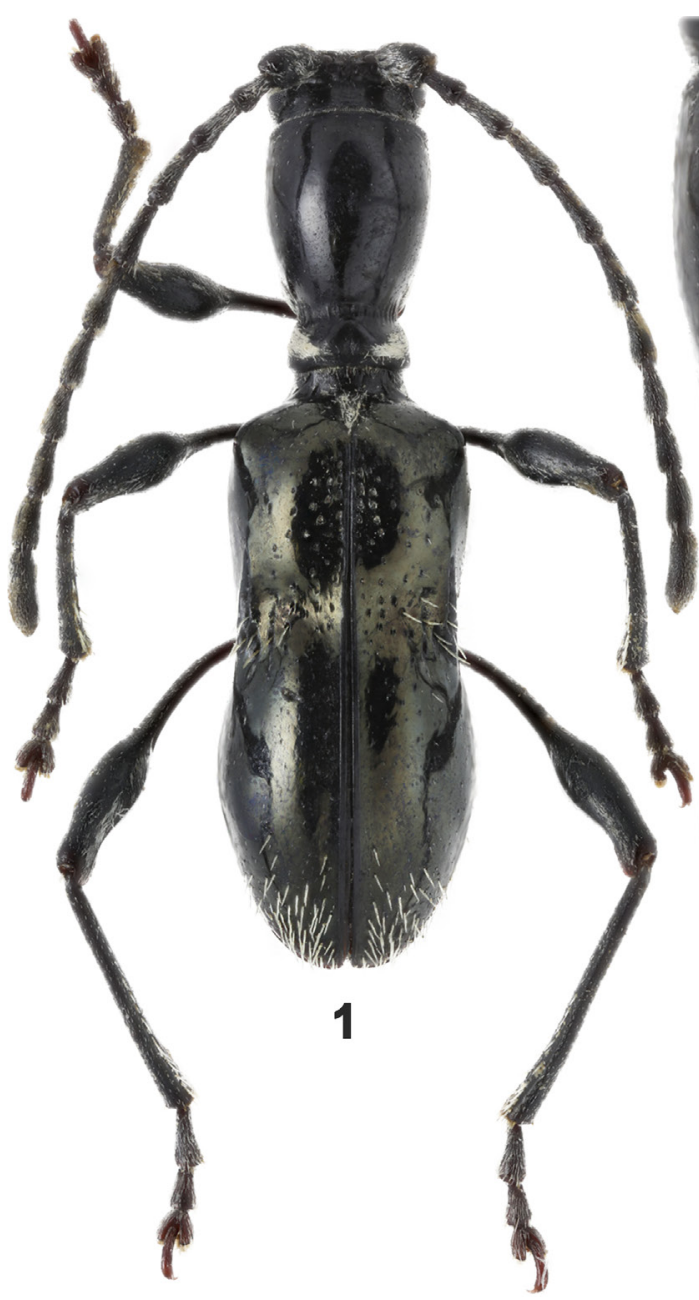

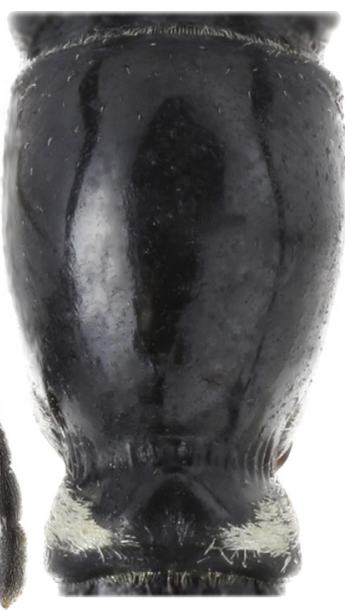

2

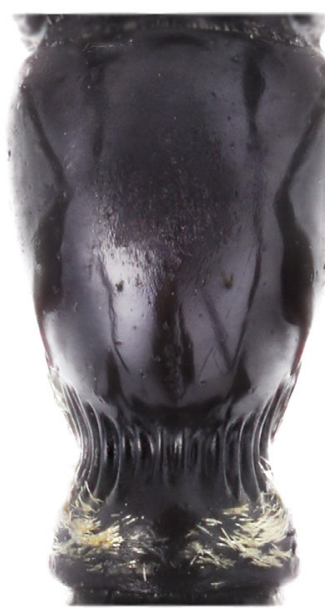

5

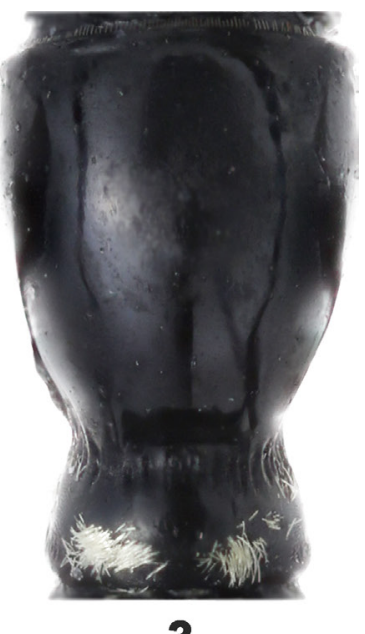

3

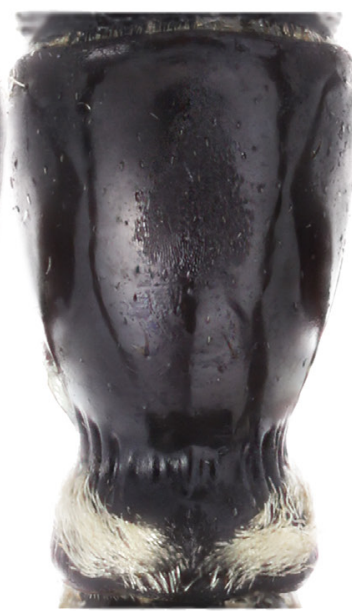

6
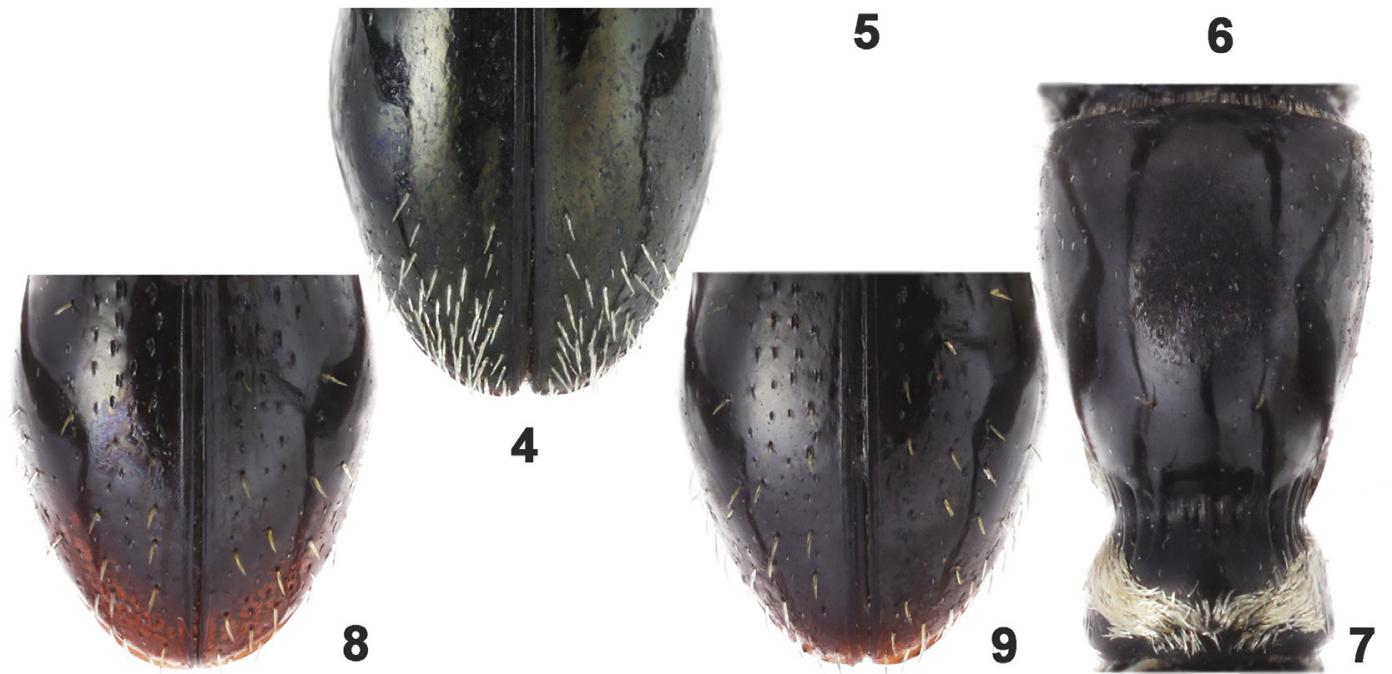

Figs 1-9. Clytellus Westwood, 1853.

1, 2, 4-C.philippinus sp. n., female, holotype 3-C. philippinus sp. n., female, paratype; 5-9- C. tatianae Miroshnikov, 2014, males (5, 7, 9 - USNM; 6, 8 - cAM). 1 - habitus; 2, 3, 5-7 - pronotum; 4, 8, 9 - apical part of elytra.

Рис. 1-9. Clytellus Westwood, 1853.

1, 2, 4 - C. philippinus sp. n., самка, голотип; 3 - C. philippinus sp. n., самка, паратип; 5-9 - C. tatianae Miroshnikov, 2014, caмцы (5, 7, 9 - USNM; 6, 8 - сАМ). 1 - общий виА; 2, 3, 5-7 - переднеспинка; 4, 8, 9 - вершинная часть надкрылий. 

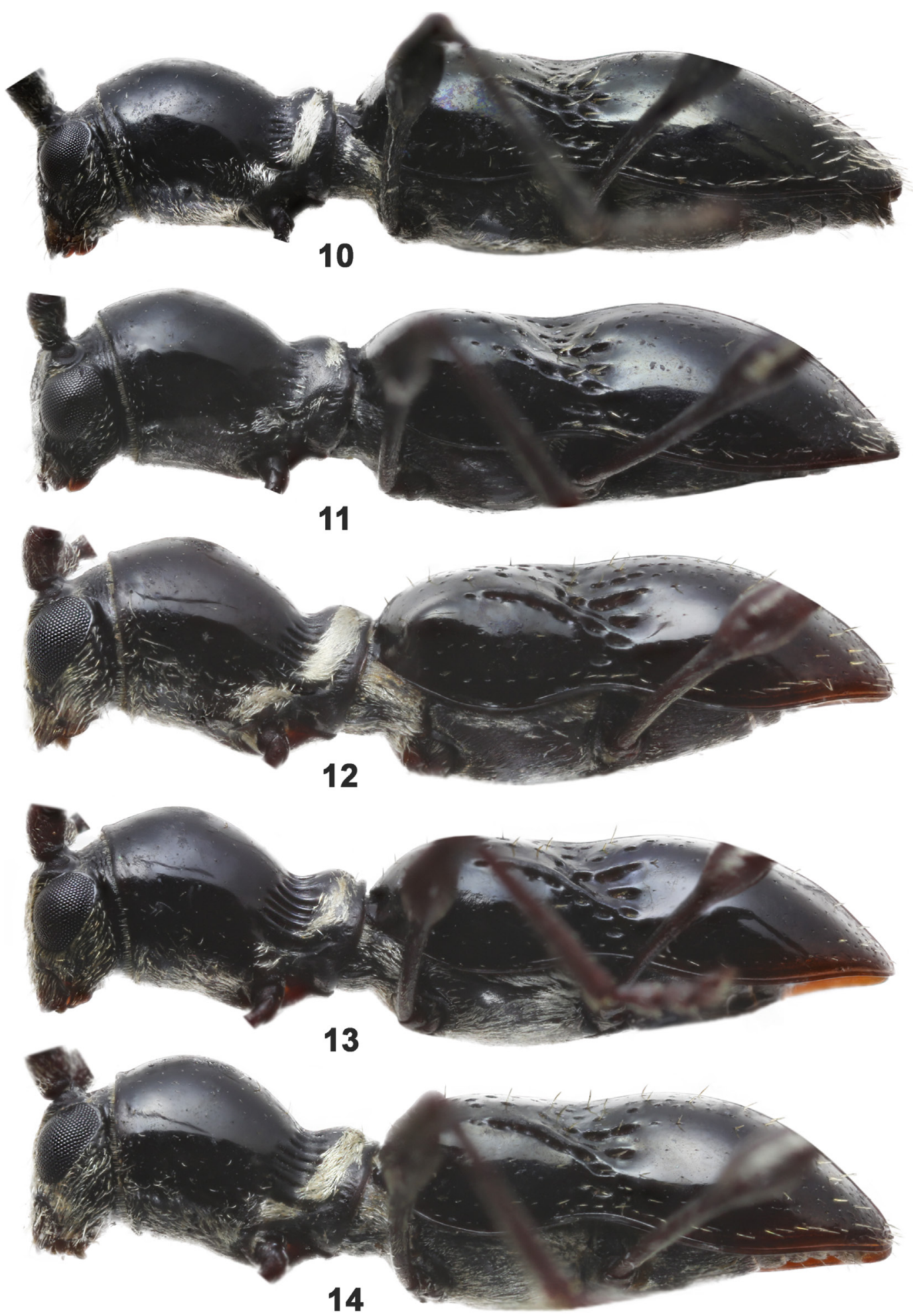

Figs 10-14. Clytellus Westwood, 1853, habitus, lateral view.

10 - C. philippinus sp. n., female, holotype; 11 - C. philippinus sp. n., female, paratype; 12-14 - C. tatianae Miroshnikov, 2014, males (12 - cAM; $13,14-$ USNM)

Рис. 10-14. Clytellus Westwood, 1853, общий виА сбоку.

10 - C. philippinus sp. n., самка, голотип; 11 - C. philippinus sp. n., самка, паратип; 12-14 - C. tatianae Miroshnikov, 2014, самцы (12 - сAM; $13,14-$ USNM) 
longitudinal grooves in the area of constriction in front of the base.

Description. Female. Body length $4.8-6.3 \mathrm{~mm}$, humera width $1.2-1.6 \mathrm{~mm}$. Almost entirely black with lighter tarsi partly or antennae mostly and legs partly dark reddish-brown, apex of elytra reddish; pronotum and elytra shiny; elytra with a clear, metallic greenish-cupreous or mostly blue lustre.

Head with a flat frons; antennomere 2,1.18-1.33 times as long as isthmus between antennal cavities; antennae extended noticeably behind middle of elytra; antennomere 1, 1.2-1.23 $1.08-1.1,1.05-1.13$ or $1.02-1.04$ times as long as $3^{\text {rd }}, 4^{\text {th }}, 5^{\text {th }}$ and $6^{\text {th }}$ respectively; antennomere $2,1.54-1.57$ times as long as wide; last antennomere 1.52-1.61 times as long as penultimate one.

Pronotum 1.6-1.62 times as long as wide at apex, 2.12.13 times as long as width at base; apex 1.29-1.33 times as broad as base, the very base 1.19-1.26 times as broad as constriction in front of base; moderately convex; area of constriction in front of base with longitudinal grooves, these being more sharp and longer mainly on sides; longitudinal groove at bottom of this constriction well- expressed; remaining surface with individual, very small, mostly unclear punctures.

Elytra 2.46-2.49 times as long as wide at humeral width, in apical half 1.09-1.11 times as broad as humeral width; a strong depression before middle, a moderately convex surface behind; basal part with coarse or rough, heterogeneous, punctures, densest ones on either side lateral to suture, as well as on sides, including area of depression, with longitudinal row of coarse or rough, oblong-oval, confluent or connivent punctures in the form of groove; apical half with small punctures forming on each elytron more or less clear, longitudinal, long rows.

Prosternum with an obliterated sculpture; its profile straight (Figs 10, 11); prosternal process at apex noticeably wider than between procoxae; mesosternal process clearly or noticeably narrower than prosternal process between coxae; metepisterna with a barely visible denticle at their apex; $1^{\text {st }}$ (visible) sternite 1.36 1.38 times as long as all following (visible) sternites combined.

Last tarsomere with 2 claws not fused at base.

Setation mainly as follows: base of pronotum in the form of a well-developed fascia (Figs 2, 3), scutellum, partly pro- and mesosterna, almost completely both metasternum and $1^{\text {st }}$ (visible) sternite clothed with more or less dense, recumbent, white setae; head, antennae, partly pronotum, venter and legs clothed with similar, but sparser setae; head, partly antennae, pronotum, as well as elytra, venter and, partly, legs covered by more or less long, sparse, on elytra mainly more robust and more numerous in their apex (Fig. 4), erect or suberect, light setae.

Remarks. The holotype lacks the right anterior leg, while the paratype lacks the left metatarsus.

Etymology. The name of the new species is derived from the Philippine Archipelago, the terra typica.
Clytellus shibatai Hayashi, 1977

Remarks. The USMN collection contains a specimen collected at Bukit Fraser [= Fraser's Hill], Western Malaysia, Pahang, $3^{\circ} 42^{\prime} \mathrm{N} / 101^{\circ} 44^{\prime} \mathrm{E}$ (May 1955). This represents the southernmost locality for C. shibatai [Miroshnikov, 2014].

\section{Clytellus malayanus Hayashi, 1977}

Remarks. The USMN collection harbours 3 specimens collected in the environs of Kuala Lumpur, Malaysia (with the following dates: 8.12.1935, 1 ex and 23.02.1936, 2 ex). This represents a new locality for C. malayanus [Miroshnikov, 2014, 2015].

\section{Clytellus mononychus Holzschuh, 2003}

Remarks. The USMN collection contains 2 specimens collected at Bukit Fraser, Western Malaysia, Pahang (with the following dates: 17.06.1935 and 30.05.1936). This represents a new locality for $C$. mononychus [Miroshnikov, 2014].

\section{Acknowledgements}

We are very grateful to Steven W. Lingafelter (USNM) for the opportunity to study the museum material, to Luboš Dembický (Brno, Czech Republic) who has provided some specimens from his private collection. We are deeply indebted to Kirill V. Makarov (Moscow Pedagogical State University, Russia) for his help in the preparation of the photographs.

\section{References}

Miroshnikov A.I. 2014. A review of the genus Clytellus Westwood, 1853, with notes on its systematic position and descriptions of eleven new species (Coleoptera: Cerambycidae). In: Advances in studies on Asian cerambycids (Coleoptera: Cerambycidae). Papers by Alexandr I. Miroshnikov, dedicated to the memory of Dr. Judson Linsley Gressitt. Krasnodar - Moscow: KMK Scientific Press Ltd.: $133-237$.

Miroshnikov A.I. 2015. Additions to reviewing the genus Clytellus Westwood, 1853 (Coleoptera: Cerambycidae). 1. Caucasian Entomological Bulletin. 11(2): 369-381, Color plates 5-8. 